\title{
Research into Our College English Teaching Team Construction
}

\author{
Changyu Li \\ Foreign Languages Department, North China Institute of Science \& Technology \\ Beijing Yanjiao, 101601, China \\ E-mail: frank1588@163.com
}

Received: July 20, 2011

doi:10.5539/ells.v1n2p82
Accepted: August 19, 2011

Published: December 1, 2011

URL: http://dx.doi.org/10.5539/ells.v1n2p82

\begin{abstract}
Teaching team and the construction of high-level teachers team is a key construction project in the college undergraduate teaching quality engineering, and it is an important guarantee to strengthen the teaching team construction, which will enhance the reform of higher education and improve the quality of undergraduate education. College English teaching team construction is conducive to promote college English teaching reform and improve the quality of teaching. Our college English teaching team is aimed at building up the team construction model "two centers, three teaching sections for support, exquisite course construction as the platform, second classrooms for practice bases" so as to achieve such goals as "first-class teachers team, first-class teaching contents, first-class teaching methods, first-class textbooks, first-class teaching management, first-class autonomous learning experimental base for students". College English teaching team construction will contribute to make the goal of college English as national elaborate course, enhance students' comprehensive English language abilities, and promote school college English teaching reform.
\end{abstract}

Keywords: College English, Teaching team, Team construction model, Teaching quality, Training of young teachers

\section{Introduction}

Dean of Foreign Languages Department Professor Luan Yuqin, responsible for our college English teaching team construction, is actively engaged in college English curriculum reform and research, contributes to a long-term commitment to college English course construction, and has a deep academic attainments and innovation spirit with a unity, team spirit, stronger organization, management and leadership skills. The teaching team is aimed at building up the team construction model "two centers, three teaching sections for support, exquisite course construction as the platform, second classrooms for practice bases" so as to achieve such goals as "first-class teachers team, first-class teaching contents, first-class teaching methods, first-class textbooks, first-class teaching management, first-class autonomous learning experimental base for students". By means of changing education thought and education concept as the guide and improving education quality as the core, with the reform of the teaching contents and means for the key and the construction of teachers team and teaching conditions as the basis, and with curriculum management as the guarantee and the organic integration of college English classroom teaching and network teaching as the breakthrough, we strive to make National College English Course and teaching team building. After the efforts of five years or so, we'll be able to have more excellent college English teachers, more advanced course teaching system, teaching methods and teaching means, make the breakthrough in the construction of teaching materials and course teaching network system, and play the rule of the elaborate course demonstration and radiation in order to strengthen the course construction and improve the teaching quality of our college.

\subsection{A brief introduction of college English teaching team}

College English teaching team is a teaching team undergoing more than ten-year teaching reform and practice, with the fine tradition and innovation spirit. In the process of college English grade-classified teaching reform and college English course construction at the provincial level, this team gradually formed one for young teachers as the backbone. Of college English teaching team, there are 36 professional teachers, including six professors, eight associate professors, 21 lecturers; among them, there are 24 teachers with master degree, accounting for $67 \%$ of the total number.

College English course teaching team undertakes the work of college English graded teaching in our college, and other course such as bear the basic courses for English-majors, English as a second foreign language for 
English-majors and Japanese-majors, college English cultural background knowledge perspectives, British and American poetry appreciation, practical English writing, business secretarial English and so on. After more than ten-year development, the team teachers' professional title structure, the structure of the educational level, age structure, learn margin structure has a reasonable structure optimization, and the team is rational, vigorous, united and progressive. With the modern education technology application as the breakthrough point, this teaching team keeps updating the teaching concept, cultivate students' comprehensive English abilities as objectives, improve the teaching level as the guarantee, and actively promote the reform of college English teaching model and contents so as to play a good exemplary role in training students' knowledge, abilities and creative spirit. So the experts insides and outsides peer out the good opinions of the teachers and students. In June, 2008, College English Course was ranked as provincial elaborate course, and for nearly three years the teaching team has acquired a number of provincial teaching achievements, and won several prizes in the ninth and tenth session of "the Star of the Century" the English Speech Contests and even the prizes of excellent organization; and the team teachers gradually forms has our own characteristics of teaching concept and teaching methods, and college English teaching reform has stepped on to a new level and contributes to the quality of undergraduate education in our college.

\section{The Features and Advantages of College English Teaching Team}

\subsection{Team features}

College English teaching team is a teaching team undergoing more than ten-year teaching reform and practice, with the fine tradition and innovation spirit. The team teachers' professional title structure, the structure of the educational level, age structure, learn margin structure has a reasonable structure optimization, and the team is rational, vigorous, united and progressive. The full-time teachers, with rich teaching and work practice experiences, have higher teaching level and a strong sense of responsibility; and part-time teachers all have abundant network engineering and network management experiences, involved in the course design and construction, and also bear the autonomous learning management of English course.

\subsection{The features of college English course}

In college English classroom teaching, we first pay attention to learning and training of basic English knowledge and skills, and maintain that language skill training and comprehensive quality training should be combined.

We practice college English graded teaching, establish and promote computer-based college English classroom teaching model, establish and perfect web-based college English teaching reform to realize students' autonomous learning, and to combine college English classroom teaching with network curriculum teaching and students' autonomous learning.

We contribute to the combination of traditional classroom teaching, second classroom activities and network teaching platform.

We accumulate English teaching reform research achievements to develop simultaneously the basic scientific research and teaching.

Students' autonomous learning and teachers' guidance and management have been united organically.

We try to create both students' individualized learning environments and campus learning atmosphere.

\subsection{The reform measures in college English teaching}

In college English teaching, we changed teacher-centered classroom teaching model, and set up a new interactive English learning system of "teacher-directed, student-centered, teaching textbooks as the foundation, modern information technology as support, training of students' comprehensive English language competence as the goal"; the team teachers also improve the three-dimensional learning environment "classroom teaching as priority, multimedia courseware, web-based classroom, personalized autonomous learning as complementary, second classroom activities for comprehensive quality practice", and create and perfect the dual systems of teacher-oriented and student-oriented teaching evaluation.

Teach students in accordance with their aptitude, and carry out classification requirements and dynamic management. Students can be divided into two levels of A and B, and according to the different levels of students, we teach students in accordance with their aptitude and complement classification guidance. Through two years' study, Grade A students are expected to reach higher level in the College English Curriculum Requirements, while Grade B students achieve the general requirement. Those outstanding students from Grade B who complete their required studies and the final result is excellent can enter A level of learning, but according to the bottom out system, those students from Grade A will be forced to enter Grade B.

Combine classroom teaching and autonomy learning. Classroom teaching organized and implemented by teachers 
highlights teaching of learning methods and skills, and through demonstration, interpretation, tutoring and inspection forms, teachers guide and supervise students' finishing learning tasks. For those projects needed repetition practice such as listening comprehension and reading, students can complete autonomous learning through teaching software in the language center.

Combine traditional classroom teaching and multimedia teaching based on modern education technology. The reform and innovation of modern teaching means contribute greatly to the college English course construction. In the past few years the team teachers have used the modern network and media teaching means to make electronic courseware in combination with the teaching experiences and characteristics so that the classroom content can be greatly enriched and students' interests in English learning can be stimulated.

Combine curriculum teaching and extracurricular activities. Classroom teaching and extracurricular activities can be organically combined through English corner, English club, English FM radio, all kinds of English speech contests, open web-based language environment and multimedia classrooms so as to extend effectively the classroom contents and activities outside the class and provide the rich varieties of language application environment for students, so that the stereo and organic college English learning model can be constituted and mutually infiltrated to make English teaching and learning, learning and application blended into the three-dimensional environment where classroom, network and extracurricular activities are combined.

Combine process assessment and formative assessment. We change the previous single form of evaluation, and aggravate the weight coefficient of students' performance in the process assessment, where process assessment and summative assessment account for $30 \%$ and $70 \%$ respectively each semester.

\subsection{Resources construction and network teaching}

We have already bought and installed College English Course Learning Platform provided by the Foreign Language Teaching and Research Press, which becomes an important platform for network teaching and course learning along with the construction achievements of the provincial elaborate course "College English Course" as the foundation. The course website provides students with course introduction, learning resources, problem sets and sample volume data, where teachers and students can realize the course communication important platform. We strive to create the task-based and collaborative training model of students' autonomous learning competence. Based on the construction of computer network technology to realize the electronization and networking of college English teaching and learning and promote the fusion of classroom teaching and extracurricular activities and even the fusion of online and offline learning.

At present, there are five network classrooms with 276 seats in the Foreign Languages Department, and the computer-aided English autonomous learning center has been set up for students' extracurricular independent network learning. In addition, our college spent 1.5 million yuan building two college English web-based teaching experimental bases each with 90 seats for students' autonomous learning.

Campus network has been constantly under construction, especially in the past three years campus network has covered most of the campus buildings, including college teaching buildings, office buildings, student dormitories, and staff dormitories that are in access to network. Students can take advantage of computer centers and library electronic reading rooms for learning English course.

\section{Achievements in College English Teaching Team Construction}

In course teaching and course construction process college English teaching team members actively do teaching reform research and have made great teaching research results. In the last five years, the results of teaching reform are very significant:

3.1 Teaching reform promotes the construction of curriculum group, and the construction of elaborate courses provides a good platform for teaching reform.

In October, 2005 Practical English became the program for Hebei Provincial Elaborate Courses, and in May, 2010, this provincial elaborate course was evaluated in acceptance. In November, 2007 Basic English became the program for Hebei Provincial Elaborate Courses; In June, 2008, College English became the program for Hebei Provincial Elaborate Courses; In April, 2007 Written Translation became the program for College Elaborate Courses; In May, 2008 English Grammar became the program for College Elaborate Courses; In January, 2010 British Literature became the program for College Elaborate Courses; In June, 2010, Advanced English became the program for College Elaborate Courses

3.2 Teaching reform promotes the scientific research, and teachers' professional level constantly increases and their teaching abilities have been gradually strengthened.

In the past four years college English teaching team members issued 55 papers, published openly 12 teaching 
materials; The total numbers of teaching and scientific research programs go up to 21 , including 3 provincial programs, of which "2009 English Teaching and Teaching Methods for Non-degree Colleges" won the second prize in the fifth Hebei Excellent Teaching Achievements; "A Study of Diagnosis and Countermeasures of English Classroom Teaching Effects" won the third prize of the fifth Hebei Teaching Achievements. The team teachers win the prizes in the provincial English teaching competitions and speech contests from 2006 to 2010, and our college has won the excellent organization prizes for years.

3.3 Teaching reform enhances the steady implementation of college English graded teaching, students' practical abilities have been improved, and their passing rates in college English Band 4 and the entrance exams for postgraduate schools have been increased year by year.

It is very beneficial to carry out college English graded teaching and establish and perfect the college English teaching reform network based on the computer and the classroom college English teaching model, so that we can achieve students' autonomous learning to promote intercultural communicative competence and perfect module teaching system. At the same time college English teachers furthest encourage students to participate in language practice activities, which will be helpful for students to master solid basic language skills and develop students' abilities of autonomous learning and good habits of study, so that students cab be encouraged to take part in various competitions of language skills. Our students won many prizes and got outstanding achievements in the National English Contest for College Students, Hebei "Star of Century" English Speech Contest, "CCTV Cup" National English Speech Contest in Hebei Province, etc. Especially in recent years, our students' cumulative passing rate of College English Band 4 goes beyond more than $60 \%$; and their passing rate of the entrance exams for postgraduate schools increased year by year, and even for some departments of our college it exceeds even more than $20 \%$.

3.4 Teaching reform attracted the attention of related colleges and universities and urge teachers to contact advanced teaching ideas so that their abilities of steering classroom teaching has been gradually strengthened and the consciousness of their responsibility has been improved.

Our teaching reform is more creative compared with some domestic similar colleges, and the teaching reform and the achievements of teaching research have also attracted attention from some experts and teachers. Teaching team members has been carrying out the educational reform and scientific research while teaching, and constantly take and adjust effective language learning strategies and teaching methods to design classroom activities and perfect the teaching model and improve students' language communicative competence, so that students' autonomous learning has been promoted and students can find and solve the problems in language learning and cultural contrasts. In addition, some teachers have the honor to get such title as teaching famous teachers, model ethics, excellent teaching quality awards, and excellent teachers, etc. and the honorary.

In the past several years the teachers from Shandong Institute of Business and Technology, Institute of Disaster Prevention, and North College of Beijing University of Chemical Industry etc. paid a visit to our college for inspection and communication about teaching experiences and college English curriculum research. In the national college English teaching seminars, Professor Luan Yuqin and Professor Li Changyu discussed some of the achievements and research results about the provincial elaborate courses with some related teachers from other provinces and cities, and to some extent, some construction achievements of the provincial elaborate courses have been under the application in teaching and research.

\section{The Training of Young College English Teachers}

College English teaching team established the ideas of talents introduction and talents training, and maintain the system of teacher qualification certificates and teaching qualification certificates. The Department of Foreign Languages require that newcomers should be under strict pre-job training and then get teaching qualifications; in the meanwhile, teachers must be trained abbot of teachers' professional moral values and education regulations in order to improve teachers' professional dedication and ethics. The Department of Foreign Languages also laid down "Eleventh Five-Year Plan" teachers team planning, the training and guidance plan of young teachers to absorb unceasingly the highly-educated teachers and academic leaders; and young teachers are also encouraged to work hard at in-service study for master's degree or doctorate degree, or select and send young excellent teachers to famous universities at home and abroad for further study, so that the age structure, the educational level structure and the title structure of a technical post can optimized. In addition, teachers are encouraged to strive for the national study opportunities at the government.

The Department of Foreign Languages plans to perfect teaching management system and select young key teachers to join in the national exquisite course construction training hosted by the Ministry of Education so as to be exposed to the national training course resources and help to improve teaching quality. The Department of Foreign Languages also support young teachers to participate in college English teaching forum and even academic 
conferences held by the Ministry of Education, and invite domestic famous experts and scholars to open lectures and deliver academic reports for more channels of young teachers' development; and the Department actively participates in the construction of College "131" Talents Project, implement the reasonable echelon construction plan of talents and academic leaders, encourage young teachers to establish academic research directions in order to drive and accelerate the construction of teaching staff and promote the rapid development of the curriculum construction.

\subsection{College teaching famous teachers}

Luan Yuqin was honored as the fifth college teaching famous teachers of 2009, and Li Changyu was honored as the sixth college teaching famous teachers of 2010.

\subsection{College "131" Talent Project}

Luan Yuqin, Li Changyu, Zheng Yanping and Yangyue in turn have been awarded as the college subject leaders, and Wangmei, Jin Xiaoli and Zhang Xueqin in turn have been was named as the college key teachers.

\subsection{Go abroad at the government as visiting scholars or for a visit and inspection}

Luan Yuqin and Li Changyu went to American North Carolina University at Pembroke and several other colleges or universities for a visit and inspection; Ji Guie went to Australia for study as a visiting scholar; Hao Hongyao went to America for study as a visiting scholar; Zheng Yanping and Tang Pingping went to the University of California at Los Angeles for about six days of the bilingual teaching training, and also went to English Training Center of the University of California At Los Angeles.

\subsection{About winning the provincial English teaching contests}

In October, 2006, Zhang Xueqin and Wuqian won the second prizes in the ninth "Star of Century" English Speech Contest in Hebei Universities; In October, 2007, Xu Huafeng won the second prize in the ninth "Star of Century" English Speech Contest in Hebei Universities; In October, 2008, Wangqiao and Wang Chengxia won the third prize in the tenth "Star of Century" English Speech Contest in Hebei Universities; In May, 2010, Zhangyue won the second prize of Listening \& Speaking Group in the first "Waijiaoshe Cup" National College English Teaching Contest in Hebei Province, and Wangqiao won the third prize of Integrated Course Group; In November, 2010, Lili won the third prizes in the Eleventh "Star of Century" English Speech Contest in Hebei Universities.

\section{The Planning of College English Teaching Team Construction}

\subsection{The overall goal of the construction}

The teaching team is aimed at building up the team construction model "two centers, three teaching sections for support, exquisite course construction as the platform, second classrooms for practice bases" so as to achieve such goals as "first-class teachers team, first-class teaching contents, first-class teaching methods, first-class textbooks, first-class teaching management, first-class autonomous learning experimental base for students". By means of changing education thought and education concept as the guide and improving education quality as the core, with the reform of the teaching contents and means for the key and the construction of teachers team and teaching conditions as the basis, and with curriculum management as the guarantee and the organic integration of college English classroom teaching and network teaching as the breakthrough, we strive to make National College English Course and teaching team building. After the efforts of five years or so, we'll be able to have more excellent college English teachers, more advanced course teaching system, teaching methods and teaching means, make the breakthrough in the construction of teaching materials and course teaching network system, and play the rule of the elaborate course demonstration and radiation in order to strengthen the course construction and improve the teaching quality of our college.

\subsection{The main contents of the construction}

Our college English teaching team is aimed at building up the team construction model "two centers, three teaching sections for support, exquisite course construction as the platform, second classrooms for practice bases." After three years of construction, we strive to achieve the teaching model "experience interaction", which fully embodies the education concept "learner-centered, teacher-directed" and the learning concept "independence, cooperation, experience and interaction", and promote students' English language abilities and the coordinated development of quality education so as to realize the change of English learning from knowledge to ability and from the language foundation to the application of language. Through the experience interactive network learning environment construction and the construction of the second classroom practice base, we can develop students' learning communication platform, build up the atmosphere of students' college English learning, and expand the channel of students' language contact so as to promote students' English proficiency and even the coordinated development of 
the students' comprehensive English language abilities and enhance college English teaching reform of our college.

\subsection{The major measures of the construction}

Strengthen the construction of the teaching staff team. Such measures as introduction and self-cultivation make English teachers cherish posts and devote wholeheartedly to teaching work, and keep the sustainable development of circulation in the teaching and the scientific research.

Constantly update and improve college English graded teaching system reform, further reform college English course graded teaching assessment measures and teaching contents and teaching methods, adopt the modern education technology, and strive to achieve the organic integration of classroom teaching and network teaching in order to deepen college English learning autonomy and improve the quality of teaching and students' learning efficiency.

Use the national three-dimensional textbooks, and strengthen the construction work of college English teaching materials. The team teachers further study the teaching textbooks and reasonably design course contents according to the actual situation of our students, and actively write high-quality textbooks or teaching auxiliary materials.

Constantly update and enrich college English online learning resources, perfect college English network course system, and achieve online college English curriculum video. We try to make perfect the network learning guidance and question-answering module module, strengthen the inspection of the network course study, and regard students' online learning results as an important element of their performance.

Give full play to the role of college English second classroom, and actively participate in the provincial or college English contests and speech contests, and seek opportunity for students' social practice to improve students' communicative abilities.

\subsection{The expected achievement of the construction}

Our college English teaching team is aimed at building up the team construction model "two centers, three teaching sections for support, exquisite course construction as the platform, second classrooms for practice bases." Two centers refer to College English Teaching Research Center and College English Autonomous Learning Center; and Deputy Director of the Department of Foreign Languages is responsible for College English Teaching Research Center that contribute to college English teaching, scientific research and even the research of college English test Band 4 and 6; and College English Autonomous Learning Center is attached to Language Experimental Center and responsible for the construction of the college English autonomy learning base and the network teaching resources and students' autonomous learning, etc.

Based on college English curriculum construction, the team is intended to improve the quality of teaching and talent training benefits, and further enhances the ideological quality, academic training and business abilities of team members. We'll make full use of the construction achievements of the provincial elaborate course to deepen and extend college English teaching team construction.

The team will continue to deepen teaching reform, promote the reform and innovation of course system, teaching contents and teaching methods, and reform and perfect the evaluation system to promote the quality education.

Through introduction and cultivation we'll bring up a number of subject leaders with high academic level and scientific research abilities and modern education innovation consciousness in order to create a high-quality excellent teaching team.

\section{Conclusion}

Our college English teaching team is aimed at building up the team construction model "two centers, three teaching sections for support, exquisite course construction as the platform, second classrooms for practice bases." After three years of construction, we strive to achieve the teaching model "experience interaction", which fully embodies the education concept "learner-centered, teacher-directed" and the learning concept "independence, cooperation, experience and interaction", and promote students' English abilities and the coordinated development of quality education. So we can develop students' learning communication platform, build up the atmosphere of students' college English learning, and promote students' English proficiency and enhance college English teaching reform of our college.

\section{References}

Cohen, A. D. (1990). Language Learning: Insights for Learners, Teachers, and Researchers. New York: Newbury House/HarperCollins.

Higher Education Department, The Ministry of Education. (2007). College English Curriculum Requirements. 
Beijing: Foreign Language Teaching and Research Press.

Kramsch, C. (1999). Context and Culture in Language Teaching. Shanghai: Shanghai Foreign Language Education Press.

Widdowson H. G. (1978). Teaching Language as Communication. Oxford University Press. 